American Journal of Pharmacology and Toxicology 6 (3): 96-101, 2011

ISSN 1557-4962

(C) 2011 Science Publications

\title{
Toxicological Evaluation of Aspilia Africana Leaf Extracts in Mice
}

\author{
${ }^{1}$ Oko, O.O.K., ${ }^{2}$ E.A. Agiang, ${ }^{3}$ E.E. Osim and ${ }^{4}$ O.R. Asuquo, \\ ${ }^{1,2}$ Department of Animal Science, Faculty of Agriculture \\ ${ }^{3}$ Department of Physiology, Faculty of Basic Medical Sciences \\ ${ }^{4}$ Department of Human Anatomy, Faculty of Basic Medical Sciences \\ ${ }^{1,2,3,4}$ University of Calabar, Calabar, Nigeria
}

\begin{abstract}
Abtract: Problem statement: The degree of toxicity of crude extracts of Aspilia Africana (Bush marigold) leaf on the basis of routes and dosages of administration were investigated. 204 healthy, male Swiss albino mice (20-25g) were used in three consecutive studies. Approach: In the first and second study, oral and intraperitoneal doses of 100, 500, 1000, 2000 and $4000 \mathrm{mg} \mathrm{kg}^{-1}$ body weight of aqueous, chloroform or ethanolic extract were administered to mice. $0.2 \mathrm{~mL}$ of distilled water was given to the control group as placebo. Mortality and behavioural changes were monitored at 1, 2, 4, 6, 24,48 and $96 \mathrm{~h}$ post administrations. In the third study, higher doses of 4,000, 8,000, 12,000, 16,000 and $20,000 \mathrm{mg} \mathrm{kg}^{-1}$ body weight aqueous or ethanolic extract were orally administered to fresh groups of mice. Results: Results revealed that the degree of toxicity of Aspilia africana leaf was extractant, dose and route of exposure responsive. Signs of behavioral toxicity; nervous and respiratory disorders and piloerections fluctuated in mice. Results indicated that the medium Lethal Dose $\left(\mathrm{LD}_{50}\right)$ was greatest for the aqueous extract and least for the chloroform extract. Oral exposure had significantly greater $\mathrm{LD}_{50}\left(\mathrm{p}<0.001\right.$, Av. value $\left.=8,194.84 \mathrm{mg} \mathrm{kg}^{-1}\right)$ compared to intraperitoneal exposure with an average of $232.55 \mathrm{mg} \mathrm{kg}^{-1}$. Conclusion: These findings support the common practice of oral administration of either aqueous or ethanolic extract of Aspilia africana as a medicinal decoction in herbal medicine. The study concludes that oral administration of up to $10,000 \mathrm{mg} \mathrm{kg}^{-1}$ body weight of aqueous and ethanolic extracts of Aspilia africana leaf are safe for human and animal use.
\end{abstract}

Key words: Aspilia africana, behavioural effects, leaf extracts, route of exposure, respiratory disorders, reproductive risks to animals, focusing attention

\section{INTRODUCTION}

The identification of more than 20,000 medicinal plant species of tropical origin by the World Health Organisation (Gullece et al., 2006) has contributed immensely to the advancement of Complementary and Alternative Medicine (CAM). Currently, the identification, validation and formulation of animal management and health care policies are the focus of renewed interest in most ethnoveterinary researches (Shapoval et al., 1994; Izzo et al., 1995; Souza et al., 2002). These studies include the diversification of traditional plants to include some weed species (Njoroge et al., 2004; Oluyemi et al., 2007; Schultes, 1994) had earlier opined that focusing attention on the plants used by indigenous people is the most effective method of identifying plants that may contain useful bioactive substances.

In most rural communities in Africa, primary health care delivery services remains dependant on the use of several medicinal plants since synthetic drugs have proven to be prohibitively expensive and unavailable (Ngari, 2010). Nevertheless, studies on the efficacies of these tropical plants as new sources of natural, effective, cheaper and potentially less toxicdrugs has not been completely explored (Njoroge et al., 2004; Barbieri et al., 2002).

Aspilia africana (Asteraceae) is a perennial herbaceous plant with long history of traditional medicinal and agricultural uses (Carew et al., 1980). The plant is commonly known as haemorrage or iodine plant due to its ability to stop bleeding. Traditional communities in Africa and Asia use this herb as a bactericide, anti-inflammatory, astringent and wound healing agents (Akobundu, 1987; Gill, 1992; Adeniyi and Odufowora, 2000). Oral decoction of the leaves is reported to relief febrile headache (Gill, 1992), quicken delivery in females (Obute and Adubor, 2007) as well

Corresponding Author: Oko, O.O.K., Department of Animal Science, Faculty of Agriculture, University of Calabar, Calabar, Nigeria 
as to cure other ailments including lumbago, sciatica and stomach disorders (Biser, 1998).

Several studies revealed that various leaf extracts of Aspilia africana have varying biological activities. (Macfoy and Cline, 1990) reported that the ethanolic extract could exhibit in vitro gastroprotective, antiinflammatory and antibacterial effects. (Dimo et al., 2002) showed that its methanolic extract reinforced the vascular smooth muscle contraction. Aqueous extract of Aspilia Africana leaf have shown varying degree of biological activities against bacteria, fungi and yeast (Taziebou et al., 2007). Okoli et al. (2007) also reported that its ethanolic extract caused extracellular $\mathrm{Ca}^{2+}$ dependent increase in vascular tone.

Recent studies however indicated some concern on the health risk of the extensive use of Aspilia africana plant. Oluyemi et al. (2007) showed that intraperitoneal administration of the methanolic extract of Aspilia africana leaf to wistar albino rats caused significant delay in their estrus cycles and severe damages to their uterine tissues. (Eweka, 2009) similarly revealed that an oral administration of the aqueous extract of Aspilia Africana leaf could distort the histology of the ovaries in female wistar rats, thus impairing fertilization. These studies suggest that Aspilia africana plant could be toxic as well as pose some health and reproductive risks to animals.

This present study was designed to evaluate the effects of route of administration and varying doses of different extracts on the degree of toxicity of Aspilia africana leaf and their impact on the behavioural responses in Swiss albino mice.

\section{MATERIALS AND METHODS}

Identification of plant material: Fresh leaves of Aspilia africana were collected in January, 2010 from local gardens at the University of Calabar and authenticated by Mr. Frank Apejoye of the Department of Botany, University of Calabar. A voucher specimen (No.252) was deposited at the herbarium section of the Department of Botany, University of Calabar for further reference.

Preparation of extract: The leaves were sorted to remove any contaminants, dead matter and sand particles. They were air-dried for $96 \mathrm{~h}$ and the dried leaves were ground to fine powder to form Aspilia africana leaf meal using a hammer mill fitted with a $1 \mathrm{~mm}$ screen. $100 \mathrm{~g}$ of leaf meal was measured into three conical flasks and soaked in $600 \mathrm{~mL}$ of distilled water, $80 \%$ ethanol and chloroform solution, respectively for $48 \mathrm{~h}$ at room temperature. Each mixture was filtered into $250 \mathrm{~mL}$ conical flask with Whatman filter paper no.1. The filtrates were then concentrated in vacuo $\left(40^{\circ} \mathrm{C}\right)$ to produce gel-like aqueous (AeAal), ethanolic (EeAaL) and chloroform (CeAaL) extract of Aspilia africana leaf, respectively. The percentage extract yields were also determined. Appropriate stock solutions were prepared by serial dilution (Dapper et $a l ., 2007)$ on the day of experiment.

Experimental protocol: Two hundred and four (204) healthy, male Swiss albino mice $\left(20-25 \mathrm{~g}^{-1}\right)$ bred at the Experimental Laboratory of the Department of Zoology, University of Calabar, Calabar were used for the acute toxicity test Table 1 . The clinically healthy mice were kept under standard environmental conditions at temperature of $27-29^{\circ} \mathrm{C}$ and $12 \mathrm{~h}$ photoperiod. For three (3) days, the animals had free access to water and were fed rat chows (Vital Feeds Nigeria Limited) ad libitum to enable them acclimatize to their metabolism cages.

Acute toxicity test was performed according to the Organization of Economic Co-operation and Development's guidelines for testing of chemicals (OECD, 2004). To investigate the effects of route of administration (intraperitoneal or oral adminstration) on the degree of toxicity of each Aspilia africana leaf extract, three studies were conducted (Lorke, 1983).

Table 1: Distribution of mice for acute toxicity tests

\begin{tabular}{|c|c|c|c|}
\hline $\begin{array}{l}\text { Route/dose of administration } \\
(\mathrm{mg} / \mathrm{kgBw})\end{array}$ & $\begin{array}{l}\text { Number in } \\
\text { aqueous } \\
\text { experiment }\end{array}$ & $\begin{array}{l}\text { Number in } \\
\text { chloroform } \\
\text { experiment }\end{array}$ & $\begin{array}{l}\text { Number in } \\
\text { ethanolic } \\
\text { experiment }\end{array}$ \\
\hline \multicolumn{4}{|c|}{ Intraperitoneal administration1st study } \\
\hline 0 & 4 & 4 & 4 \\
\hline 100 & 4 & 4 & 4 \\
\hline 500 & 4 & 4 & 4 \\
\hline 1000 & 4 & 4 & 4 \\
\hline 2000 & 4 & 4 & 4 \\
\hline 4000 & 4 & 4 & 4 \\
\hline $\begin{array}{l}\text { Total number of mice } \\
\text { used in the first experiment }\end{array}$ & & & 72 \\
\hline \multicolumn{4}{|c|}{ Oral Administration (mg/kgBw) 2nd study } \\
\hline 0 & 4 & 4 & 4 \\
\hline 100 & 4 & 4 & 4 \\
\hline 500 & 4 & 4 & 4 \\
\hline 1000 & 4 & 4 & 4 \\
\hline 2000 & 4 & 4 & 4 \\
\hline 4000 & 4 & 4 & 4 \\
\hline $\begin{array}{l}\text { Total number of mice used } \\
\text { in the second experiment }\end{array}$ & & & 72 \\
\hline \multicolumn{4}{|c|}{ Oral administration $(\mathrm{mg} / \mathrm{kgBw}) 3 \mathrm{rd}$ study } \\
\hline 4,000 & 4 & 4 & 4 \\
\hline 8,000 & 4 & 4 & 4 \\
\hline 12,000 & 4 & 4 & 4 \\
\hline 16,000 & 4 & 4 & 4 \\
\hline 20,000 & 4 & 4 & 4 \\
\hline Total number of mice used & & & 60 \\
\hline in the third experiment & & & 204 \\
\hline $\begin{array}{l}\text { Grand total number of mice } \\
\text { used in the three experiments }\end{array}$ & & & \\
\hline
\end{tabular}


In the first and second studies, 24 mice were randomly assigned to six groups of four animal each. The mice were housed individually in metabolism cages. Each group was administered one of the following doses; $100 \mathrm{mg} \mathrm{kg}^{-1}, 500,1000,2000$ and $4000 \mathrm{mg} \mathrm{kg}^{-1}$ of aqueous, chloroform or ethanolic extract of Aspilia africana leaf either intraperitoneally (first study) or through oral adminstration (second study). The mice in the control group were orally administered $0.2 \mathrm{~mL}$ of distilled water as placebo. Therefore, in each experiment, a total of 72 mice were studied Table 1. The maximum volume of extracts administered was $0.4 \mathrm{~mL}^{-1}$ mouse.

Following administration, each mouse was returned to its cage and allowed access to feed and water.

The mice in cage were observed 1, 2, 4, 6, 24, 48, $96 \mathrm{~h}$ and once daily thereafter over 14 days for clinical signs of toxicity. Percentage mortalities were converted to probits (a probability unit) and plotted against the $\log _{10}$ of dose of each extract LeOra, 1994. Regression lines were also fitted by the least square method and the confidence limits for respective medium lethal dose $\left(\mathrm{LD}_{50}\right)$ values were calculated.

Oral administration of between 100 and 4,000 mg $\mathrm{kg}^{-1}$ of the three Aspilia africana leaf extracts (except chloroform at $4,000 \mathrm{mg} \mathrm{kg}^{-1}$ did not result to no mortality in mice, thus the third study was initiated.

The third study involved the random assignment of a total of 60 mice to 5 groups of 4 animals per leaf extract. Each group was orally adminstered one of the higher doses $(4,000,8,000,12,000,16,000$ and 20,000 $\mathrm{mg} \mathrm{kg}^{-1}$ ) of either aqueous, chloroform or ethanolic extract of Aspilia africana leaf. The procedures adopted in the first two studies to establish the $\mathrm{LD}_{50}$ of each extract were repeated.

\section{RESULTS}

The patterns of mortality in mice administered the various Aspilia africana leaf extracts were dose-dependent Fig. 1 and 2. Intraperitoneal and oral exposures to Aspilia africana leaf extracts revealed highly significant $(\mathrm{p}<0.001)$ influences on percentage mortality.

From the probit analysis Table 2, medium Lethal Dose (LD50 i.p) ranging from 100-398.11 $\mathrm{mg} \mathrm{kg}^{-1}$ was established in mice exposed intraperitoneally to Aspilia africana leaf extracts. The acute oral $\mathrm{LD}_{50}$ of Aspilia africana leaf Table 2 was indicated at 12,589.25
(AeAaL), 1,995.26 mg kg-1 (CeAaL) and 10,000 mg $\mathrm{kg}^{-1}$ (EeAaL).

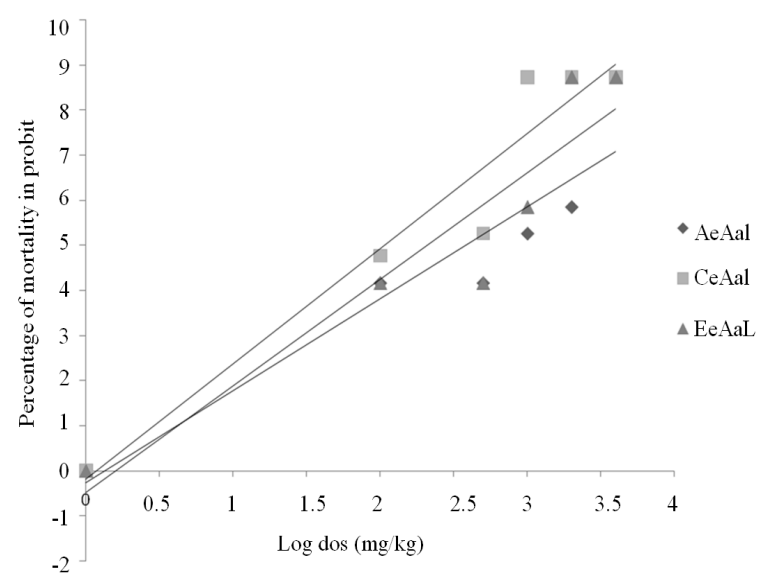

Fig. 1: Acute toxicity test following intraperitoneal (i.p) administrations of Aspilia africana leaf extracts AeAaL-aqueous extract of Aspilia africana leaf, CeAaL-chloroform extract of Aspilia africana leaf, EeAaL-ethanolic extract of Aspilia africana leaf

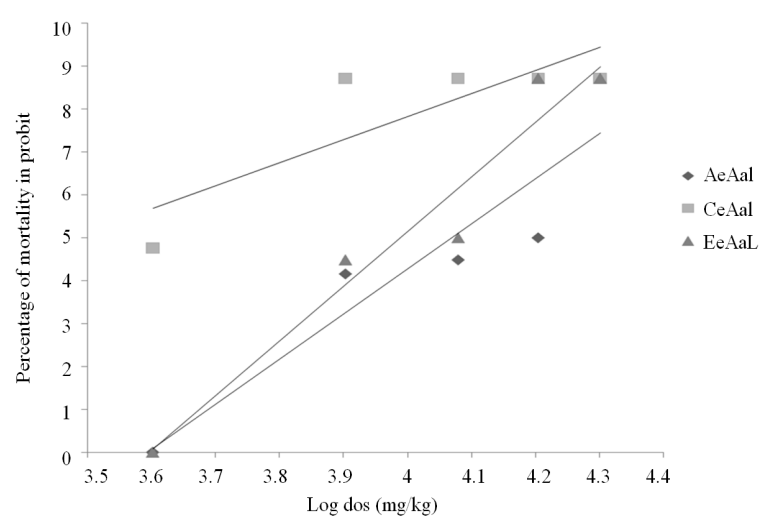

Fig. 2: Acute toxicity test following oral administrations of Aspilia africana leaf extracts AeAaL-aqueous extract of Aspilia africana leaf, CeAaL-chloroform extract of Aspilia africana leaf EeAaL-ethanolic extract of Aspilia africana leaf

Table 2: Determination of the medium lethal doses $\left(\mathrm{LD}_{50}\right)$ of Aspilia africana leaf extracts in mice

\begin{tabular}{|c|c|c|c|c|c|c|}
\hline \multirow[b]{2}{*}{ Extract } & \multicolumn{3}{|c|}{ Intraperitoneal administration } & \multicolumn{3}{|l|}{ Oral administration } \\
\hline & Prediction equation & $\mathrm{LD}_{50}$ (i.p) $\mathrm{mg} / \mathrm{kg}$ & $\mathrm{R}$ & Prediction equation & $\mathrm{LD}_{50}$ (oral) $\mathrm{mg} / \mathrm{kg}$ & $\mathrm{R}$ \\
\hline Aqueous & $Y=-0.261+2.034 X$ & 398.11 & 0.939 & $Y=-37.741+10.511 X$ & $12,589.25$ & 0.936 \\
\hline Chloroform & $Y=0.192+2.555 X$ & 100.00 & 0.966 & $Y=-13.854+5.421 X$ & $1,995.26$ & 0.842 \\
\hline Ethanolic & $Y=-0.482+2.362 X$ & 199.53 & 0.941 & $Y=-45.686+12.715 X$ & $10,000.00$ & 0.973 \\
\hline
\end{tabular}


Am. J. Pharm. \& Toxicol., 6 (3): 96-101, 2011

Table 3: Rate of lethality in mice administered Aspilia africana leaf extracts

\begin{tabular}{lrrr}
\hline \multicolumn{4}{c}{ Mortality (\%) } \\
Dose $(\mathrm{mg} / \mathrm{kg})$ & \multicolumn{1}{c}{ AeAaL } & CeAaL & EeAaL \\
\hline Intraperitoneal administration & 0.0 & 0.0 & 0.0 \\
0 & 20.0 & 40.0 & 20.0 \\
100 & 20.0 & 60.0 & 20.0 \\
500 & 60.0 & 100.0 & 80.0 \\
1000 & 80.0 & 100.0 & 100.0 \\
2000 & 100.0 & 100.0 & 100.0 \\
4000 & & & \\
Oral administration & 0.0 & 0.0 & 0.0 \\
0 & 0.0 & 0.0 & 0.0 \\
100 & 0.0 & 0.0 & 0.0 \\
500 & 0.0 & 0.0 & 0.0 \\
1000 & 0.0 & 0.0 & 0.0 \\
2000 & 0.0 & 40.0 & 0.0 \\
4000 & 20.0 & 100.0 & 33.0 \\
8000 & 33.0 & 100.0 & 50.0 \\
12000 & 50.0 & 100.0 & 100.0 \\
16000 & 100.0 & 100.0 & 100.0 \\
20000 & & &
\end{tabular}

No clear sign of toxicity was observed in mice orally exposed to $100-4,000 \mathrm{mg} \mathrm{kg}^{-1}$ of aqueous or ethanolic extracts of Aspilia africana leaf Table 3 whereas, a mortality of $40 \%$ was recorded in mice orally exposed to $4,000 \mathrm{mg} \mathrm{kg}$-1 of the chloroform extract. $100 \%$ mortality was reached following oral administration of $8,000,16,000$ and $20,000 \mathrm{mg} \mathrm{kg}^{-1}$ of chloroform, ethanolic and aqueous extract, respectively of Aspilia africana leaf Table 3. Intense behavioural changes were also dose-dependent.

Behavioral response in Mice: No clear behavioral changes were observed in mice that received low doses of extracts (100-500 mg kg-1), compared to the control group. Changes in behavior became noticeable in the groups that received $2,000 \mathrm{mg} \mathrm{kg}^{-1}$ oral exposure of chloroform extract. $15 \mathrm{~m}$ after administration, some of the animals became erratic for 5$10 \mathrm{sec}$ and remained immobile for $30 \mathrm{~m}$. $6 \mathrm{~h}$ post administration, all the mice resumed feeding.

Mild signs of intoxication were observed at a dose range of 4,000-8,000 $\mathrm{mg} \mathrm{kg}^{-1}$ oral administration. Apart from behaviors exhibited at low doses of the extracts, biting and vigorous face wiping with forelimbs were noticed. These behaviors continued for $10-20 \mathrm{~m}$. Thereafter, the mice became immobile, paralyzed and laid on their abdomen with limbs stretched. Piloerection occurred and the animals became cold. Mortality was recorded $8 \mathrm{~h}$ after administration.

At a dose of $12,000-20,000 \mathrm{mg} \mathrm{kg}^{-1}$, marked behavioural changes occurred. Respiration became forced and irregular within 15-20 m of administration. This led to spasm and death (mortality) began $45 \mathrm{~m}$ post administration. Necropsy revealed the lungs became haemorrhagic with extreme pulmonary oedema.

\section{DISCUSSION}

Intraperitoneal exposure showed that mortality could reach $100 \%$ when mice are exposed to $1,000 \mathrm{mg}$ $\mathrm{kg}^{-1}, 2,000$ and 4,000 mg kg-1 of chloroform, ethanolic and aqueous extract of Aspilia Africana leaves, respectively. Hashemi et al. (2008) earlier reported that oral administration of $2,000 \mathrm{mg} \mathrm{kg}^{-1}$ of aqueous extract of some selected herbs was non- toxic to birds. Mice that received $100-500 \mathrm{mg} \mathrm{kg}^{-1}$ of aqueous or ethanolic extracts of Aspilia africana leaf had the lowest mortality. Mortality remained significantly $(\mathrm{p}<0.05)$ higher in those that received equivalent doses of the chloroform extract. The reason for high mortality in mice exposed to chloroform extract could be associated with liver damage as suggested by Kent (1998) when chloroform gas was administered to rat.

The present findings indicated that oral exposure to aqueous and ethanolic extracts of Aspilia africana leaf below 4,000 $\mathrm{mg} \mathrm{kg}^{-1}$ appeared to be non-toxic probably because the circulatory levels of the toxic substances were metabolically lowered below the lethal threshold thus inhibiting its lethal effect (Kent, 1998). The acute toxicity test showed that the chloroform extract was of higher toxicity in mice than the ethanolic extract while the aqueous extract was the least toxic. There were indications of significant effects of the route of administration of the Aspilia africana leaf extracts. In all extracts, intraperitoneal administration was of higher toxicity, even at doses as low as $500 \mathrm{mg} \mathrm{kg}^{-1}$, compared to higher oral doses of up to $12,000 \mathrm{mg} \mathrm{kg}^{-1}$.

The higher values obtained for $\mathrm{LD}_{50}$ under oral administration further indicated that oral administration of Aspilia africana leaf extracts could be safe for human and animal use. The aqueous extract seemed to be of relatively lower toxicity based on its higher $\mathrm{LD}_{50}$ value. This further revealed that aqueous extract of Aspilia africana leaf was relatively of low toxicity compared to the ethanolic extract, while chloroform extract appeared to be the most toxic of the three extract forms. This observation supports the common practice of oral administration of either aqueous or ethanolic extract of Aspilia africana as a medicinal decoction in herbal medicine (Sofowora, 1993).

Previous studies had reported oral $\mathrm{LD}_{50}$ values of $894 \mathrm{mg} \mathrm{kg}^{-1}$ (Okoli et al., 2007) and 6,600 $\mathrm{mg} \mathrm{kg}^{-1}$ (Taziebou et al., 2007) for methanolic and aqueous extracts of whole plant and leaf of Aspilia africana. Other studies reported acute oral $\mathrm{LD}_{50}$ of $810,2,220$, 4,590, 980 and $1,562 \mathrm{mg} \mathrm{kg}^{-1}$ for cinnamaldehyde, beta-ionone, thymol (Lee et al., 2004) and Adansonia 
digitata leaves, respectively. These reports implied that the $\mathrm{LD}_{50}$ of a plant material was dependent on the route of administration, the principles present as well as the types of extractant used.

The relatively high toxicity of CeAaL could suggest that metabolic detoxification was inhibited due to the rapid and extensive rate of absorption into the animals' bodies. The high cost of chloroform and concerns about its biohazard to humans and animals (Kent, 1998) justify its limited use in folk medicine.

These findings and other field studies support the insinuations that Aspilia africana leaf is of low to moderate toxicity $\left(>5,000 \mathrm{mg} \mathrm{kg}{ }^{-1}\right)$ based on the recommendation of Olson (2007). Recent studies have shown some toxic effects of AaL on animal physiology which have been reported to include; reductions in uterine tissue and duration of estrus cycle as well as antiovulatory effects in female rats (Oluyemi et al., 2007; Taziebou et al., 2007; Okwuonu et al., 2007). However, no report on such effect on farm animals has been published.

Behavioural responses observed were consistent with the findings of Eno et al. (2000). Intraperitoneal administration was marked with intense behavioural changes at as low as $500 \mathrm{mg} \mathrm{kg}^{-1}$ of extracts due to rapid rate of absorption into the blood stream.

\section{CONCLUSION}

The differences in the degree of toxicity exhibited in mice exposed to the aqueous, chloroform and ethanolic extracts of Aspilia africana leaf suggested that they could have different effects on the physiology of animals. The oral exposure is the safer route of administration of crude extracts of Aspilia africana leaf. Results from the $\mathrm{LD}_{50}$ studies revealed that the chloroform extract of Aspilia africana leaf was relatively more toxic compared to the aqueous and ethanolic extract forms. These findings support the common practice of oral administration of either aqueous or ethanolic extract of Aspilia africana as a medicinal decoction in herbal medicine. Based on the results from this study, it is therefore recommended that oral administration of up to $10,000 \mathrm{mg} \mathrm{kg}^{-1}$ body weight of aqueous and Ethanolic extracts of Aspilia Africana leaf are safe for human and animal use.

\section{REFERENCES}

Adeniyi, B.A. and R.O. Odufowora, 2000. In-vitro antimicrobial properties of aspilla africana (compositae). Afri. J. Biomedi. Res., 3: 167-170.

Akobundu, I.O., 1987. Weed Science in the Tropics: Principles and Practices. Chichester. 1st Edn., Wiley, Chichester, ISBN: 0471915440, pp: 522.
Biser, J.A., 1998. Really wild remedies-Medicinal plant use by animals. FONZ.

Barbieri, H.F., T. Ueda-Nakamura, B.P.A. Filho, D.A.G. Cortez and J.C.P. Mello et al., 2002. Effect of plant extracts used in folk medicine on cell growth and differentiation of Herpetomonas samuelpessoai (Kinetoplastida, Trypanosomatidae) cultivated in defined medium. Acta Scie. Biol. Health Sci., 243: 657-662.

Carew, B.A.R., A.K. Mosi, A.U. Mba and G.N. Egbunike, 1980. The Potential of Browse Plants in the Nutrition of Small Ruminants in the Humid Forest and Derived Savanna Zones of Nigeria. In: Browse in Africa, International Livestock Research Institute, (Ed.)., ILRI, pp: 307-312.

Dapper, D.V., B.N. Aziagba and O.O. Ebong, 2007. Antiplasmodial effects of the aqueous extract of Phyllantus amarus Schumach and Thonn against Plasmodium berghei in Swiss albino mice. Nig. J. Physiol. Sci., 22: 19-25. PMID: 18379613

Dimo, T., P.V. Tan, E. Dongo, P. Kaintchouing and S.V. Raktoniria, 2002. In vitro vascular smooth muscle contractile activity of Aspilia africana extract on rat aortic preparations. Phamazie, 57: 421-423. PMID: 12116882

Eno, A.E., R.S. Konya and J.O. Ibu, 2000. Toxicological and haematological effects of a venom extract from the sea anemone-Bunodosoma cavernata. Global J. Pure Appl. Sci., 6: 349-358.

Eweka, A.O., 2009. Histological studies of the effects of oral administration of Aspilia africana (Asteraceae) leaf extract on the ovaries of female wistar rats. Afri. J. Tradi., Complement. Altern. Med., 6: 57-61.

Gill, L.S., 1992. Ethnomedical Uses of Plants in Nigeria. Uniben Press, Benin City, ISBN: 9782027200, pp: 276.

Gullece, M., A. Aslan, M. Sokmen, F. Sahin and A. Adiguzel et al., 2006. Screening the antioxidant and antimicrobial properties of the lichens Parmelia saxatilis, Platismatia glauca, Ramalina pollinaria, Ramalina polymorpha and Umbilicaria nylanderiana. Ramalina pollinaria. Phytomedicine, 13: 515-521. DOI: 10.1016/j.phymed.2005.09.008

Hashemi, S.R., I. Zulkifli, M.H. Bejo, A. Farida and M.N. Somchit, 2008. Acute toxicity study and phytochemical screening of selected herbal aqueous extract in broiler chickens. Int. J. Pharmacol., 4: 352-360. DOI: 10.3923/ijp.2008.352.360 
Izzo, A.A., G.D. Carlo, D. Biscardi, R.D. Fusco and N. Mascolo et al., 1995. Biological screening of Italian medicinal plants for antibacterial activity. Phytother Res., 9: 281-286. DOI: 10.1002/ptr.2650090410

Kent, C., 1998. Basics of Toxicology. 1st Edn., John Wiley and Sons, New York, ISBN: 0471299820, pp: 402.

Lee, K.W., H. Everts and A.C. Beynen, 2004. Essential oils in broiler nutrition. Int. J. Poult. Sci., 3: 738752.

Lorke, D., 1983. A new approach to practical acute toxicity testing. Arch. Toxicol., 54: 275-287. DOI: 10.1007/BF01234480

Macfoy, C.A. and E. I.Cline, 1990. In vitro antibacterial activities of three plants used in traditional medicine in sierra leone. J. Ethnopharmacol., 28: 323-327. DOI: 10.1016/0378-8741(90)90083-6

Ngari, F., 2010. Forest Plants Used in Ragati, Mt Keny. 1st Edn., VDM Verlag Dr. Mueller e.K., Saarbrücken, ISBN: 3639215281, pp: 76.

Njoroge, N.G., W.R. Bussmann, B. Gemmill, L.E. Newton and V.W. Ngumi, 2004. Utilisation of weed species as sources of traditional medicines in central Kenya. Lyonia, 7: 71-87.

Obute, G.C. and G.O. Adubor, 2007. Chemicals detected in plants used for folk medicine in South Eastern Nigeria. Ethnobotanical Leaflets, 11: 173194.

OECD, 2004. OECD Guidelines for the Testing of Chemicals. 1st Edn., OECD, USA., ISBN: 9264017968, pp: 244.

Okoli, C.O., P.A. Akah, S.V. Nwafor, A.I. Anisiobi and I.N. Ibegbunam et al., 2007. Anti-inflammatory activity of hexane leaf extract of Aspilia africana C.D. Adams. J. Ethnopharmacol., 109: 219-225. DOI:10.1016/j.jep.2006.07.037
Okwuonu, C.U., K.A. Oluyemi, B.D. Grillo, O.A. Adesanya and V.O. Ukwenya et al., 2007. Effects of methanolic extracts of Aspilia africana leaf on the ovarian tissues and weights of wistar rat. Internet J. Altern. Med.

Olson, K.R., 2007. Poisoning and drug overdose. 5th Edn., Lange Medical Books/McGraw-Hill, New York, ISBN: 0071443339, 736.

Oluyemi, K.A., U.C. Okwuonu, P.G. Baxter and T.O. Oyesola, 2007. Toxic Effects of Methanolic Extract of Aspilia africana Leaf on the Estrous Cycle and Uterine Tissues of Wistar Rats. Int. J. Morphol, 25: 609-614.

Schultes, R.E., 1994. Amazonian Ethnobotany and The Search for New Drugs. In: Ethnobotany and the Search for New Drugs, G.T. Prance, D. Chadwick and J. Marsh, (Eds.). John Wiley and Sons, ISBN: 0471950246, pp: 106-115.

Shapoval, E.E.S., S.M. Silveira, M.L. Miranda, C.B. Alice and A.T. Henriques, 1994. Evaluation of some pharmacological activities of Eugenia uniflora L. J. Ethnopharmacol, 44: 137-142. DOI: 10.1016/0378-8741(94)01178-8

Sofowora, A., 1993. Medicinal Plants and Traditional Medicine in Africa. 2nd Edn., Spectrum Books, Ibadan, ISBN: 9782462195, pp: 289.

Souza, L.K.H., C.M.A.D. Oliveira, P.H. Ferri, S.C. Santos and J.G.D.O. Junior et al., 2002. Antifungal properties of Brazilian cerrado plants. Braz. J. Microbiol., 33: 247-249.

Taziebou, L.C., F.X. Etoa, B. Nkegoun, C.A. Pieme and D.P.D. Dzeufiet, 2007. Acute and subacute toxicity of Aspilia africana leaves. Af. J. Traditional Complementary Alt. Med., 4: 127-134. 